\title{
Getting into good company
}

\section{Mariano Troccoli: Being in a company, in a hierarchical structure, gives you more motivation to achieve your goals.}

$\mathrm{N}$ ew $\mathrm{PhDs}$ used to approach industrial postdoctorates with some trepidation. Such positions had a reputation for allowing little, if any, publication. PhDs who accepted them felt that they were sealing off their options of any future academic career. But although these issues warrant consideration, they are not true in every case.

Publication records vary from company to company. And for people willing to do multiple postdocs, an industrial fellowship before or after an academic one offers a way to explore the idea of a career in industry without committing to it.

\section{PUBLICATION CONSIDERATION}

Prospective industrial postdocs may want to investigate a company's policy and see what other postdocs have published while in similar positions. Some companies have a history of their scientists publishing, such as IBM's nanotechnology research section in Yorktown Heights, New York, and in Zurich, Bell Labs in Murray Hill, New Jersey, and Genentech in South San Francisco.

That record played a factor in Sachdev Sidhu's decision to accept a postdoc with Genentech - a decision that proved sound. "I published more than 10 papers in the past two years, more than I could have published in an academic setting," Sidhu says.

Unlike those in academia, an industrial postdoc can lead directly on to a job in the same place. Both Sidhu and his colleague Sarah Hymowitz accepted offers from the company after completing fellowships there. Biotech firms are more likely to hire their own former postdocs than are drug companies, but policies vary and exceptions are often made for valuable postdocs.

Another question to ask is how long-term and basic a research project will be. Short-term, applied goals in industrial research can be problematic for people with a more academic bent. Kurt Lust, now a researcher at the University of Leuven in Belgium, did a postdoc at United Technologies in Hartford, Connecticut, conducting numerical bifurcation analysis. "We were busy with some nice things, but never had the time to demonstrate that they were nice," says Lust.

Companies that include long-term and even basic science projects can offer more interesting postdoc

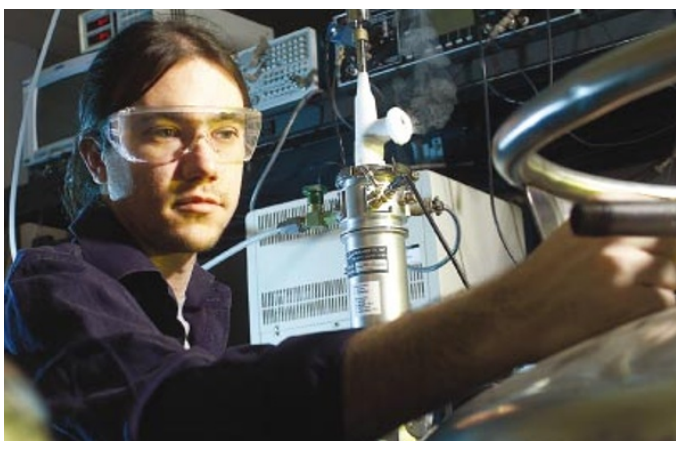

programmes. Martin Bammerlin, who is involved in nanoscience research at IBM's Research Laboratory in Zurich, says that he is doing basic science, not projects involving building countless prototypes.

Long-term research often depends on how much money a company can invest in research. "At Bell Labs, basic research is still an important issue. This is something that is essential for the company," says Mariano Troccoli, who has a two-year contract in Bell Labs' semiconductor physics research department.

Many industrial postdocs pick up skills or experiences they would not have received in academia. Bernd Gotsmann, who does nanoscience research as a postdoc at the IBM Zurich Research Laboratory in Switzerland, says that some of the experience he has picked up there may be valuable in academia especially being exposed to teamwork. He has also enjoyed interacting with people from different fields.

\section{DIFFERENT APPROACHES}

Gotsmann, who is a physicist, worked with people from the computer sciences, engineering and chemistry. "They all have different approaches to the problems," says Gotsmann. Those interactions could be at a premium if he returns to academia: many projects are becoming increasingly interdisciplinary, even though few academics have the experience of interacting outside their departments.

Project and time management skills also tend to be emphasized more in industry. This is especially true for big projects, says Marina Brockway, who did a $\mathrm{PhD}$ at Kiev University and a postdoc at the University of California, Irvine, before joining Honeywell of Minneapolis, Minnesota, in an industrial postdoc programme. "Trying to resolve a problem in a timeline, trying to make a problem manageable" is often lacking in academic research, she says.

That environment may not be for everyone. But being exposed to it - whether or not you intend to stay in it - can be valuable, says Troccoli, who is enjoying the fast-paced environment of his Bell Labs fellowship. "Being in a hierarchical structure in a company gives you more motivation to achieve your goals," he says.

Alexander Hellemans is a science writer in Naples, Italy.
Web links

Bell Labs

www.bell-labs.com

IBM Zurich

www.zurich.ibm.

com

IBM at Yorktown Heights

www.watson.ibm.

com

Genentech

www.gene.com/ gene/research United Technologies

www.utrc.utc.com Honeywell

www.honeywell.

com/index.html 